\title{
MEMBENTUK KARAKTER WIRAUSAHA PADA KEPALA SEKOLAH TK/ RA DAN PAUD SE-KABUPATEN NGANJUK MELALUI WORKSHOP KEWIRAUSAHAAN
}

\author{
Ema Nurzainul Hakimah ${ }^{1}$, Sri Aliami ${ }^{2}$, Subagyo ${ }^{3}$ \\ Program Studi Manajemen Universitas Nusantara PGRI Kediri \\ 1emahakimah@unpkediri.ac.id \\ ${ }^{2}$ srialiami@unpkediri.ac.id \\ 3subagyo@unpkediri.ac.ic
}

\begin{abstract}
ABSTRAK
Pengabdian masyarakat hasil gagasan bersama antara dosen program studi manajemen dan pengurus IGTA/IGRA, HIMPAUDI se-kabupaten Nganjuk ini dilatar belakangi semakin resahnya kepala sekolah karena persaingan antar sekolah yang semakin ketat. Masalah dalam mengelola sekolah, memperbaiki kualitas sesuai standar nasional pendidikan, rendahnya tingkat kesejahteraan guru dan bagaimana mendapatkan sumber pendapatan selain SPP (sumbangan pembinaan pendidikan), memerlukan penambahan wawasan, pembinaan dan pendampingan. Tujuan dari program pengabdian masyarakat ini adalah (1) meningkatkan pengetahuan dan ketrampilan, kesadaran serta memotivasi guru TK/RA dan PAUD, khususnya kepala sekolah sehingga mempunyai mindset yang kuat terdapat profesi wirausaha dan karakter wirausaha yang harus melekat kuat dalam profesinya sebagai kepala sekolah atau guru; (2) menjiwai dan melaksanakan profesinya dengan karakter-karakter unggul wirausaha; (3) mampu melaksanakan tugas fungsi pokok kepala sekolah/madrasah mengacu sesuai standart pengelolaan sekolah, meliputi perencanaan program, pelaksanaan rencana kerja, pengawasan dan evaluasi, kepemimpinan sekolah, (5) sistem informasi sekolah; dan yang terakhir adalah mampu mengaplikasikan bussines plan, ilmu manajemen pemasaran dan beberapa strategi pemasaran dalam rangka menciptakan keunggulan bersaing.

Dalam rangka mencapai tujuan pengabdian masyarakat kali ini, maka kami harus mempunyai metode yang tepat untuk kegiatan ini. Beberapa metode yang kami pilih untuk menjawab tujuan pengabdian ini antara lain dengan bimbingan teknis, sosialisasi dan workshop yang didalamnya terdapat kegiatan seminar motivasi, kegiatan praktek langsung membuat rencana bisnis, merancang strategi pemasaran,, dan rencana lanjutan pendampingan kepala sekolah dan kelompok usaha yang dibentuk.

Dari hasil kegiatan yang telah dilakukan dapat ditarik kesimpulan bahwa: (1) Meningkatkan kesadaran, motivasi dan mampu merubah mindset peserta menjadi wirausaha. Sebelumnya mereka hanya berpikir dan bertanya bagaimana memajukan sekolah jika tidak memiliki dana yang besar, pesimisme yang tinggi terhadap keadaan sekolah yang terus menghadapi persaingan ketat dan terlalu mengandalkan bantuan pemerintah untuk melakukan kegiatan. Setelah mengikuti kegiatan ini, semangat dan mindset mereka mengalami perubahan yang signifikan, hal ini dibuktikan dengan rancangan kegiatan yang dituangkan dalam proposal bisnis mereka saat presentasi. Suara, senyum dan gesture mereka menunjukkan ekspresi orang yang sedang bersemangat menyongsong harapan baru. (2)
\end{abstract}


Meningkatnya ilmu pengetahuan mereka tentang marketing untuk jasa pendidikan. Mereka mengenali karakteristik bidang usahanya yaitu jasa pendidikan. Pemasaran dan strateginya tentu saja berbeda antara produk berupa barang dan jasa. Hal ini bener-bener memberikan pencerahan dan menambah wawasan dan keilmuan mereka. Banyaknya peserta yang bertanya, berlanjut dalam diskusi informal saat istirahat dan tidak ada yang beranjak dari tempat duduk merupakan bukti bahwa materi yang diberikan sangat diminati dan dibutuhkan oleh peserta. (3) Perbaikan soft skill dan hard skill mitra dalam bidang ilmu pengetahuan dan teknologi pemasaran, pengelolaan usaha, manajerial dan yang lebih penting dari itu adalah berubahnya mindset mereka tentang keingingan untuk menjadi pemimpin yang berjiwa entrepreneur. Keyakinan tercermin dari ide bisnis yang mereka tuangkan dan semangat mereka untuk mendapatkan pendapatan sampingan untuk meraih kesejahteraan, yang mana sebelumnya mereka hanya mengandalkan gaji sangat kecil dari sekolah.

Kata kunci: Wirausaha, persaingan, strategi pemasaran sekolah

\section{PENDAHULUAN}

Bermunculannya lembaga-lembaga pendidikan baru, pada satu sisi merupakan sinyal positif akan tingginya tingkat perhatian pemerintah ataupun masyarakat terhadap dunia pendidikan, namun pada sisi yang lain persaingan antar lembaga pendidikan itu semakin atraktif. Mudahnya perijinan untuk pendirian lembaga pendidikan baru menjadikan pemilik modal berlomba dalam sektor ini. Secara bisnis pada salah satu sektor publik yang cukup menguntungkan adalah pendidikan. Lembaga pendidikan yang berhasil tumbuh dengan baik saat ini adalah pada lembaga pendidikan anak usia dini. Perkembangan yang paling dominan terletak pada lembaga yang dikelola masyarakat, di satu sisi kondisi ini sangat menggembirakan namun di sisi lain membuat persaingan yang semakin tidak sehat. Dewasa ini persaingan antar sekolah semakin atraktif. Pemasaran untuk lembaga pendidikan multak diperlukan. Sebagai usaha jasa, sekolah harus mampu menyediakan jasa pendidikan sesuai dengan kebutuhan dan mampu memuaskan konsumen atau pelanggannya yaitu (siswa). Jasa pendidikan yang prosesnya sirkuler dan saling mempengaruhi dalam setiap elemennya perlu segera berinisiatif merubah mindset kerjanya.

Jarak atau radius sekolah yang sangat berdekatan dan sangat tidak sesuai dengan permendiknas diperparah dengan terus menurunya angka usia anak masuk sekolah akibat program Keluarga Berencana yang sukses, sehingga banyak sekolah yang tidak punya kurikulum yang inovatif dan strategi pemasaran yang cerdas 
menjadi stagnan. Kabupaten Nganjuk memiliki 1200 lembaga pendidikan RA/TK dan PAUD, sebagaimana yang disampaikan pengurus IGRA/IGTK dan HIMPAUDI kabupaten saat pertemuan awal dengan tim prodi manajemen.

Dampak selanjutnya lembaga lokal yang berbasis sumber daya terbatas semakin tersisih karena mereka kehilangan masyarakat yang mampu membayar, bahkan pada beberapa kasus terdapat banyak lembaga yang kesulitan memenuhi target anak didik dan target pemasukan keuangan karena masyarakat sasarannya memiliki kemampuan finansial yang terbatas pula. Guna memenangkan persaingan dalam bisnis pendidikan memerlukan strategi khusus dan inovatif sehingga mampu mengikuti tantangan jaman serta untuk meningkatkan akselerasi peningkatan kualitas dan profesionalisme manajemen lembaga pendidikan.

Karakter wirausaha merupakan karakter unggul dalam diri manusia yang sangat penting untuk ditumbuhkembangkan, diarahkan dan dimiliki oleh setiap manusia sehingga sukses dalam hidup. Kepala sekolah, penyelenggara pendidikan yang dalam hal ini secara bisnis disebut manajer sebuah bisnis, dipandang sangat perlu mengerti dan memahami tentang wirausaha, mampu merencankan dengan baik usahanya dan mampu mengelola usahanya sehingga maju dan berkembang. Wirausaha memiliki tempat di masyarakat sebagai profesi dapat tidak hanya dapat melakukan perbaikan dan perubahan di dalam kualitas hidup diri dan masyarakat, tetapi wirausaha juga dibuktikan dapat berperan signifikan di dalam mewujudkan kualitas diri masyarakat dan bangsa. Peningkatan jumlah wirausaha juga terus dilakukan, salah satu yang dapat dilakukan adalah dengan memberikan pelatihan terkait perancangan business plan yang diberikan pada kepala sekolah TK/RA dan PAUD. Program ini dilakukan dalam rangka memberikan motivasi kepada kepala sekolah TK/RA dan PAUD untuk menjadi kepala sekolah yang berjiwa wirausaha dan memaksimalkan nilai hidupnya sehingga mampu memenangkan persaingan, mendapatkan peserta didik yang banyak dan mempunyai kualitas pendidikan sesuai dengan 8 standart pendidikan nasional serta mampu meningkatkan kesejahteraan hidupnya dengan tidak mengandalkan gaji pokok guru yang sangat kecil. 


\section{METODE PELAKSANAAN}

Kegiatan pengabdian pada masyarakat ini dilakukan dengan metode interaksi aktif antara pelaksana kegiatan dengan kelompok sasaran yang terlibat dalam kegiatan ini yaitu kepala sekolah TK/RA, dan PAUD se Kabupaten Nganjuk. Beberapa metode pelaksanaan untuk pencapaian target yaitu kepala sekolah yang berjiwa wirausaha, dan kepala sekolah yang memahami pemasaran jasa pendidikan, tim program studi menajemen menggunakan 4 cara, yaitu: (1) seminar motivasi wirausaha, (2) bintek tentang business plan dan pemasaran jasa pendidikan, (3) praktek lansung pembuatan proposal usaha, serta (4) pelaksanaan monitoring dan evaluasi (MONEV) pelaksanaan program pengabdian pada beberapa sekolah yang dipilih secara acak mewakili beberapa kecamatan.

\section{Teknik Pelaksanaan Kegiatan}

Program "Penerapan Ipteks" ini melakukan alih ilmu pengetahuan tentang pemasaran dan keuangan sekaligus memberikan pendampingan manajemen untuk mengelola bidang usaha jasa pendidikan/ sekolah) sehingga menjadi berkualitas sesuai standart pendidikan nasional, menjadi pilihan masyarakat atau usaha produksi (snacking/ makanan ringan yang juga sudah dimiliki oleh beberapa kepala sekolah. Kegiatan ini juga diharapkan sekolah bisa mempunyai pendapatan usaha bagi lembaga yang bisa digunakan untuk mencukupi kegiatan operasional sekolah. Seluruh peserta dihari pertama akan mendapatkan materi tentang motivasi wirausaha, dengan yang berisikan (a) Kecakapan Hidup, terdiri dari : Merubah mindset diri menjadi berkarakter wirausahawan, terdiri dari : Perspektif Kewirausahaan, (Inovasi dan Strategi Usaha), dan Manajemen Usaha; (b) Keterampilan Profesi, terdiri dari : teori tentang pemasaran jasa pendidikan, strategi promosi, strategi pemasaran dan menciptakan keunggulan bersaing untuk bisnis pendidikan; dan (c). Keterampilan Usaha, meliputi bimbingan teknis dan pendampingan dalam membuat rencana bisnis (business plan) dari usaha yang dipilih oleh masing-masing peserta. Beberapa peserta yang sudah mempunyai usaha diminta untuk melakukan presentasi proposal bisnisnya dan sekaligus menunjukkan hasil kerja dari pemahaman ilmu pemasarannya, misalnya dengan 
mempresentasikan produknya, kemasannya, labelingnya, cara memasarkannya, kualitas produknya, dan sampai menciptakan saluran distribusinya.

\section{HASIL DAN PEMBAHASAN}

\section{Pelaksanaan Workshop Kewirausahaan.}

Pengabdian pada masyarakat dengan mitra kepala sekolah TK/RA dan PAUD se-kabupaten Nganjuk ini berjutuan untuk memberikan pengetahuan dan keterampilan tentang Kewirausahaan yang didalamnya terdapat materi motivasi wirausaha, pemasaran jasa pendidikan dan bimbingan teknis membuat business plan. Pengetahuan, kepribadian dan mindset yang lebih kuat sebagai wirausahawan dalam mengelola lembaga pendidikannya, meningkatkan kesejahteraan hidupnya merupakan target utama yang ingin dicapai dalam pengabdian masyarakat ini.

Materi motivasi wirausaha yang diberikan oleh para dosen manajemen yang juga sebagai wirausahawan, misalnya Dr. H. Samari dosen yang sekaligus petani, peternak dan pedagang mampu mentransfer ilmu, semangat, pengalaman dan nilainilai keberhasilan yang telah dicapainya dengan sangat menarik, sehingga para peserta bersemangat terlibat dalam diskusi tanya jawab di akhir sesi. Pengalaman praktis dan kiat usaha secara khusus disampaikan oleh para pemateri motivasi, sebagai contoh Drs. Ichsannudin, MM dimana selain dosen beliau adalah pedagang kayu dan mebelair sukses, memberikan motivasi bagaimana menemukan potensi diri, peluang usaha, dan menjalin kerjasama atau mencari hubungan bisnis sangat berhasil mengobarkan semangat dan mampu menstimulus perubahan mindset peserta. Pada akhir presentasi pemateri menyampaikan yel, tepuk tangan dan teriakan semangat wirausaha langusung jawab dan diikuti dengan ekspresi tubuh dan wajah luar biasa dari peserta. Serasa satu aula merah menyala dengan semangat baru dan jiwa-jiwa baru yang terlahir dari para kepala sekolah RA/TK dan PUAD yang menjadi peserta workshop kewirausahaan.

Ilmu pengetahuan dan strategi pemasaran jasa pendidikan disampaikan oleh Dr. Sri Aliami, Ema Nurzainul Hakimah, M.M dan Gesty Ernestivita, M.M, memberikan tambahan ilmu pengetahuan dan wawasan baru tentang manajemen pemasaran khususnya jasa pendidikan. Para peserta mengetahui tentang jenis usaha 
yang dipimpinnya saat ini, tentang karakteristik usahanya, bauran pemasarannya, bauran promosinya dan hal-hal spesifik bisnis pendidikan. Pemateri Ema Nurzainul Hakimah, MM selain dosen dengan spesifikasi pemasaran juga pendiri Yayasan Nabeeha Ulya, mempunyai pengalaman mendirikan PUAD, TK dan Madrasah Ibtidaiyah berbagai ilmu dan kiat khususnya kepada para peserta. Strategi pemasaran dan promosi yang dalam teori langsung dijabarkan dengan contoh aplikatif yang telah dilakukan oleh beliau di lembaga yang dia kelola mampu menggugah fokus dan antusiasme peserta. Peserta diberikan gambaran dan penjelasan secara detail bagaimana sebuah ilmu pengetahuan dengan mudah dan efektif diterapkan dalam kehidupan mengelola pendidikan. Sesi tanya jawab tidak disia-siakan oleh peserta untuk menyampaikan permasalahan yang selama ini mereka hadapi terutama adanya persaingan yang tidak sehat, ketidakmapuan lembaga mendanai operasional lembaga, bahkan sampai masalah manajemen sumber daya manusia juga menjadi topik pertanyaan peserta. Masalah MSDM yang dihadapi diantaranya turn over guru yang tinggi, rendahnya loyalitas, rendahnya kinerja guru dan lemahnya dukungan dari yayasan. Sehingga dengan materi ini peserta semakin baik kompetensi dan kapabilitasnya dalam menghadapi permasalahan, sekaligus kinerja mereka dalam mengelola lembaga pendidikannya akan semakin baik sesuai standart nasional pendidikan.

Hasil bimbingan teknis dari penyusunan business plan adalah kepala sekolah memiliki kemampuan praktis yang dapat digunakan untuk merancang dan mengelola usahanya dengan baik. Pembukuan yang baik, produksi yang efektif dan selanjutnya pengembangan profitabilitas yang semakin baik. Pada sesi ini juga diberikan materi tentang bagaimana meningkatkan nilai jual produk, membuat kemasan yang baik, memberi merk yang menjual karena sebagai peserta telah miliki produk. Hal ini menjadikan materi praktik dan presentasi rencana bisnis semakin menarik.

\section{Evaluasi Pelaksanaan Workshop}

Setelah dilakukan workshop dalam pengabdian masyarakat ini, selanjutnya adalah tahap evaluasi kegiatan. Evaluasi keberhasilan dilakukan untuk mengetahui adanya perubahan tingkat pemahaman perserta tentang ilmu pengetahuan dan teknologi yang disampaikan, perubahan pandangan dan memikiran mereka tentang 
karakter dan profesi wirausaha dan sekaligus penguasaan teknis merencanakan dan mengelola usaha. Kegiatan ini dilakukan dua kali yaitu sebelum dan sesudah workshop dilakukan. Adapun cara evaluasinya adalah dengan membandingkan pengetahuan dan pemahaman peserta sebelum dan sesudah workshop untuk materi kewirausahaan dan pemasaran. Peserta memahami bahwa berpikir dan bertindak dengan karakter wirausaha akan jauh memudahkankan dia dalam mengelola sekolahnya. Mereka jadi memahami bahwa karakter dan sikap mental wirausaha itu harus dimiliki apapun profesi yang ditekuni setiap orang. Pemikiran dan cara pandang yang semakin positif ini diharapkan akan membuat kesejahteraan lembaga dan pribadinya bisa semakin baik. Melakukan dengan mandiri, tidak lagi berpikir mengandalkan dana pemerintah untuk memperbaiki kualitas lembaganya, dengan menciptakan pendapatan tambahan sekolah melalui unit-unit usaha. Indikator keberhasilan berikutnya adalah bahwa peserta dapat membuat rencana bisnis sederhana, mampu menjelaskan kembali saat diberi pertanyaan dalam sesi workshop bidang pemasaran. Tabel 1 berikut ini menunjukkan kriteria dan indikator keberhasilan kegiatan pengabdian masyarakat ini.

Tabel 1 Indikator keberhasilan kegiatan

\begin{tabular}{|l|l|l|}
\hline No. & \multicolumn{1}{|c|}{ Kriteria } & \multicolumn{1}{c|}{ Indikator } \\
\hline 1. & Tingkat partisipasi & $\begin{array}{l}\text { Kegiatan pelatihan dan workshop selalu } \\
\text { dipenuhi peserta karena tingkat kehadiran } \\
\text { mencapai 100\% sesuai dengan jumlah } \\
\text { undangan yang disebarkan. }\end{array}$ \\
\hline 2. & $\begin{array}{l}\text { Tingkat pemahaman } \\
\text { peserta terhadap materi } \\
\text { pelatihan }\end{array}$ & $\begin{array}{l}\text { Wawasan dan keilmuan perserta menjadi } \\
\text { semakin luas terkait dengan ilmu pemasaran } \\
\text { dan membuat perencanaan usaha. Mereka } \\
\text { menjadi tahu dan memahami tentang jenis } \\
\text { usaha mereka, strategi pemasaran, pemilihan } \\
\text { media komunikasi atau iklan, mengerti } \\
\text { bagaimana memberi merek, mengemas } \\
\text { produk barang yang dihasilkan (nama dan } \\
\text { kemasan kripik/ kue kering), mengerti tentang } \\
\text { apa itu dan bagaimana menciptakan kepuasan } \\
\text { pada konsumen, sekaligus menciptakan CRM } \\
\text { sehingga konsumen mereka selalu loyal. }\end{array}$ \\
\hline 3. & Dampak penyuluhan & $\begin{array}{l}\text { Kemasan produk yang telah dihasilkan oleh } \\
\text { beberapa peserta menjadi lebih rapi, mampu } \\
\text { melindungi produk, mencantumkan PIRT, } \\
\text { menggunakan teknik pengemasan yang lebih } \\
\text { baik sehingga produk lebih tahan lama, } \\
\text { mampu merancang sebuah usaha berbasis }\end{array}$ \\
\hline
\end{tabular}




\begin{tabular}{|l|l|l|}
\hline & & $\begin{array}{l}\text { kemitraan dengan paguyuban siswa, mampu } \\
\text { membuat studi kelayakan bisnis, dan mereka } \\
\text { semakin bersemangat untuk mampu bersaing } \\
\text { sehat dengan sesama sekolah yang berdekatan } \\
\text { menggunakan strategi unik yang akan mereka } \\
\text { ciptakan. }\end{array}$ \\
\hline 4. & Kesesuaian materi & $\begin{array}{l}\text { Pemateri yang sesuai bidang keahliannya } \\
\text { sangat membantu dalam kelancaran } \\
\text { penyampaian informasi dan ilmu. Dimana } \\
\text { materi yang disusun dapat disampaikan secara } \\
\text { menyeluruh, rinci, terstruktur dan mampu } \\
\text { dipahami dengan baik oleh peserta workshop. }\end{array}$ \\
\hline
\end{tabular}

Rangkaian acara yang dibuat sangat nyaman, waktu istirahat yang cukup dan ice breaking yang dibuat mampu menciptakan suasana workshop menjadi tidak membosankan. Namun ada hal yang dirasa kurang nyaman oleh peserta yaitu ruangan yang cukup panas, karena semua kipas angin yang ada diruangan ternyata tidak berfungsi dengan baik. Kondisi ini sedikit terkurangi karena ruangan mempunyai fentilasi dan sangat luas untuk membantu sirkulasi udara. Moderator mampu mengendalikan jalannya workshop dengan sangat baik dan luwes, sehingga setiap tahapan dapat dilalui dengan tepat waktu. Disela-sela waktu istirahat dimanfaatkan dengan baik oleh peserta untuk menemui dan berdiskusi dengan pemateri. Pemateri pun mendekatkan diri dan berbaur dengan peserta terutama peserta yang mempunyai pertanyaan saat dalam kegiatan yang dirasa pemateri belum tuntas terjawab. Semua peserta merasa sangat puas dan mengharap akan ada kelanjutan kegiatan pengabdian masyarakat kerja sama UN PGRI Kediri Fakultas Ekonomi Prodi Manajemen dengan Dinas Pendidikan Kabupaten Nganjuk, yaitu dengan mengunjungi ke beberapa sekolah TK/RA/PAUD yang telah ikut workshop kali ini.

\section{Faktor Pendorong dan Penghambat Kegiatan}

Kegiatan pengabdian yang dirancang dan dilaksanakan bersama mitra dalam rangka menumbuhkan jiwa wirausaha dan mencapai pengelolaan usaha jasa pendidikan yang semakin baik ini, dapat disimpulkan berhasil dengan baik. Keberhasilan ini ditunjukkan dengan dukungan yang diberikan oleh peserta workshop selama kegiatan berlangsung, yaitu tingkat kehadiran peserta yang mencapai hampir 100\%, berbagai komentar dan pertanyaan yang diberikan selama 
kegiatan berlangsung, tidak ada satupun peserta yang meninggalkan acara sebelum acara berakhir, kerjasama yang sangat kompak antara penyelenggara, pemateri dan peserta, sarana prasarana yang sangat mendukung selama acara telah disiapkan dengan baik oleh panitia, bahan-bahan diskusi telah disiapkan dengan baik oleh peserta pada saat sesi unjuk kerja dan harapan kedepan dilakukan kunjungan lapangan setelah mereka menerapkan hasil workshop kewirausahaan ini.

Keberadaan nara sumber selain sebagai akademisi tetapi juga praktisi dalam usaha jasa pendidikan, misalanya Dr. Samari yang sekaligus Ketua Yayasan Pendidikan Mambaul Ulum yang menaungi TK dan Madrasah Ibtidaiyah Mambaul Ulum di Desa Mangunrejo Kecamatan Ngadiluwih Kupaten Kediri, Ema Nurzainul Hakimah, M.M. selain sebagai dosen pemasaran sekaligus Ketua Yayasan Pendidikan Nabeeha Ulya yang mengelola pendidikan non formal PAUD dan TK Khodijah sekaligus Madrasah Ibtidaiyah Al Ikhlash, Dr. Subagyo yang juga berprofesi sebagai konsultan UMKM dan pengurus KADIN Kota Kediri, Dr. Sri Aliami juga sebagai praktisi dalam pengelolaan sebuah institusi pendidikan (sebagai Wakil Rektor II UN PGRI Kediri dan beberapa nara sumber lain yang dapat mengkomunikasikan dengan baik pengalaman dan keilmuannya tentu menjadikan workshop ini lebih menarik dan aplikatif bagi para peserta.

Namun demikian ada sedikit hal yang dirasakan kurang mendukung kegiatan ini misalnya jangkauan layar yang kurang besar, sehingga peserta yang duduk dibelakang kurang maksimal melihat presentasi, ketersediaan waktu yang hanya 60 menit per pemateri sehingga ada beberapa pemateri yang tidak bisa menyampaikan materinya secara tuntas khususnya pemateri bidang pemasaran dan pengelolaan jasa pendidikan. Padatnya rundown acara sangat membatasi peserta berdiskusi secara informal dengan pemateri diluar sesi acara.

\section{KESIMPULAN}

Berdasarkan evaluasi diatas maka dapat disimpulan beberapa hal dari workshop kewirausahaan bagi kepala sekolah TK/RA dan PAUD, sebagai berikut:

1. Kegitan pengabdian ini memberikan efek tumbuhnya jiwa wirausha dikalarangan kepala sekolah sekaligus menjadi brainstorming tentang ilmu pengetahuan bidang kewirausahaan dan pengelolaan usaha. 
2. Mitra pengadian menjadi sangat termotivasi menjadi pengusaha baru sesuai dengan bidang bakat dan minat masing-masing.

3. Warga mitra merasakan kemanfaatan yang tinggi dari kegiatan pengabdian ini dan menyampaikan bahwa mereka membutuhkan pendampingan setelah mereka sudah memulai melakukan usaha dan menerapakan jiwa kewirausahaan dan ilmu pemasaran mereka dalam pengelolaan lembaga pendidikannya.

4. Diperlukan kerjasama lanjutan antara pihak dinas pendidikan non formal kabupaten Nganjuk dengan fakultas ekonomi UN PGRI Kediri, khususnya dengan program studi manajemen, sehingga output keberhasilan workshop ini dapat dilihat secara langsung.

\section{DAFTAR PUSTAKA}

Alma, B. 2004, Manajemen Pemasaran dan Pemasaran Jasa, Cetakan Keenam, Alfabeta, Bandung.

Alma, B. 2008, Kewirausahaan untuk Mahasiswa dan Umum, Alfabeta, Bandung. 